\title{
Sistem Pengendalian Kadar pH, Suhu, dan Level Air Pada Model Miniatur Tambak Udang
}

\author{
Alimuddin, ST., MT. \\ Jurusan Teknik Elektro \\ Politeknik Katolik Saint Paul Sorong \\ Ghailan11@ rocketmail.com
}

\begin{abstract}
Abstrak
Penelitian ini bertujuan merancang suatu alat mikrokontroler yang dapat memonitoring dan mengendalikan kadar PH, suhu dan level air. Sebagai tempat pengujian, dibuat sebuah bak air dengan ukuran $100 \mathrm{~cm} \times 40 \mathrm{~cm} x 60 \mathrm{~cm}$. Pada perancangan sistem terdapat beberapa bagian input sensor seperti sensor PH, sensor suhu LM35, sensor jarak ultrasonic, dan bagian output seperti tiga buah motor pompa, satu buah valve dan satubuah kincir yang digerakkan oleh motor dc 12 volt. Mikrokontroller ATMega328P yang tertanam pada arduino uno sebagai tempat pemrosesan data dari sensor yang selanjutnya akan memberikan output untuk menggerakkan aktuator dan akan ditampilakan data hasil pembacaan sensor pada PC atau. Power supply diperlukan berasal dari adaptor 12 volt yang mendapat input tegangan jala-jala PLN. Driver relay ULN2003 digunakan untuk menggerakan aktuator digunakan pada sistem. Perancangan miniature sistem ini menggunakan bahasa pemrograman $\mathrm{C}$ dan Borland Delphi 7 yang berfungsi sebagai Interface. Hasil penelitian ini menunjukkan bahwa sistem yang dibuat dapat mengendalikan nilai $\mathrm{PH}$, suhu serta level air sesuai dengan setting point yang diberikan.
\end{abstract}

Kata kunci : Monitoring, Kendali, Arduino Uno, Tambak udang, Sensor PH, sensor suhu, sensor level.

\section{Pendahuluan}

Tambak merupakan salah satu jenis habitat dipergunakan untuk kegiatan budidaya air payau yang berada di pesisir, dimana kegiatan budidaya yang dilakukan secara terus menerus dapat menyebabkan terjadinya degradasi terhadap lingkungan, yang ditandai dengan menurunnya kualitas air. Kendala lingkungan yang dihadapi dalam kegiatan budidaya diantaranya penataan wilayah atau penataan ruang pengembangan budidaya yang tidak memperhatikan daya dukung lingkungan akibat pengelolaan yang tidak tepat, sehingga menimbulkan permasalahan lingkungan dengan segala aspek komplikasinya dalam kurung waktu yang panjang $^{[1]}$.

Dalam dunia perikanan, khususnya budidaya udang air payau, untuk mengontrol kadar $\mathrm{pH}$ air payau, para petani tambak air payau masih menggunakan cara manual, yaitu dengan terlebih dahulu mengukur menggunakan sensor baik berupa $\mathrm{PH}$ meter digital maupun kertas lakmus, kemudian menambahkan sejumlah air tawar/laut sebanyak yang diperlukan dan mengukur lagi dengan sensor apakah air sudah benar-benar netral atau belum. Hal yang sama juga dilakukan pada saat hendak mengontrol suhu dan volume air masih menggunakan cara manual.

Berawal dari suatu pemikiran untuk membuat suatu sistem monitoring yang dapat melihat perubahan parameterparameter air dari suatu tambak serta dapat mengendalikan setiap terjadi perubahan parameter-parameter sampai didapatkan suatu kondisi nilai yang sesuai dengan kebutuhan pada air tambak.

Dengan memanfaatkan separangkat komputer yang dihubungkan dengan mikrokontroller melalui komunikasi serial RS-232 maka akan dibangun sebuah prototype yang dapat mengendalikan peralatan seperti valve selenoid, pompa air, motor kincir angin, dimana sistem ini dilengkapi beberapa jenis sensor yang berfungsi untuk memantau (monitoring) nilai parameter $\mathrm{pH}$, suhu dan level air pada tambak, yang cocok digunakan untuk kontrol sistem dan otomatisasi contohnya dalam otomatisasi temperatur ruangan, $\mathrm{pH}$ air, kelembaban tanah,dll.

\section{Rancangan Sistem}

Blok diagram model sistem Monitoring dan Pengendalian kadar PH, suhu, dan level air pada model tambak yang dibangun dalam penelitian ini ditunjukkan pada gambar 1 berikut

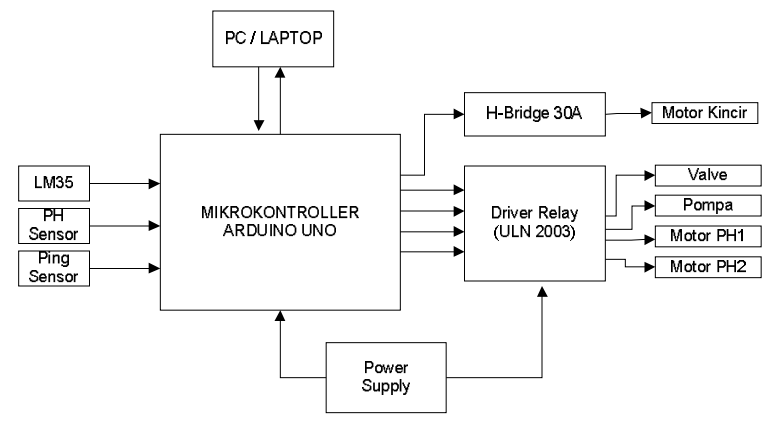

Sistem ini terdiri dari 1 unit PC / Laptop, 1 unit sensor $\mathrm{PH}, 1$ unit sensor ping parallax, 1 unit Arduino Uno yang didalamnya sudah tertanam mikrokontroller, kabel USB, 1 unit Driver Relay, 1 unit Power supply, Driver H Bridge 30A, 1 unit Motor DC 12 volt,3 unit pompa air, dan 1 unit Valve Solenoid. 
Untuk menghubungkan PC dengan mikrokontroler Arduino Uno di perlukan USB.USB adalah port yang sangat diandalkan untuk saat ini karena bentuknya yang kecil dan kecepatan transfernya yang tinggi. USB 1.1 mendukung dua modus kecepatan penuh ( $12 \mathrm{Mb} /$ detik) dan kecepatan rendah ( $1,5 \mathrm{Mb} /$ detik ).

Desain penempatan sensor.

a. PH sensor

PH sensor ditempatkan di dalam bak air dengan kedalaman $20 \mathrm{~cm}$ dari permukaan air saat ketinggian maksimum $43 \mathrm{~cm}$

b. Sensor jarak ultrasonik.

Sensor jarak ultrasonic ping parallax ditempatkan di atas bak air dengan ketinggian maksimum $75 \mathrm{~cm}$ dari permukaan bak air.

c. Sensor suhu LM35

Sensor IC LM35 ditempatkan di dalam bak air dengan kedalaman $15 \mathrm{~cm}$ dari permukaan air saat ketinggian maksimum $43 \mathrm{~cm}$

\section{Activity Diagram}

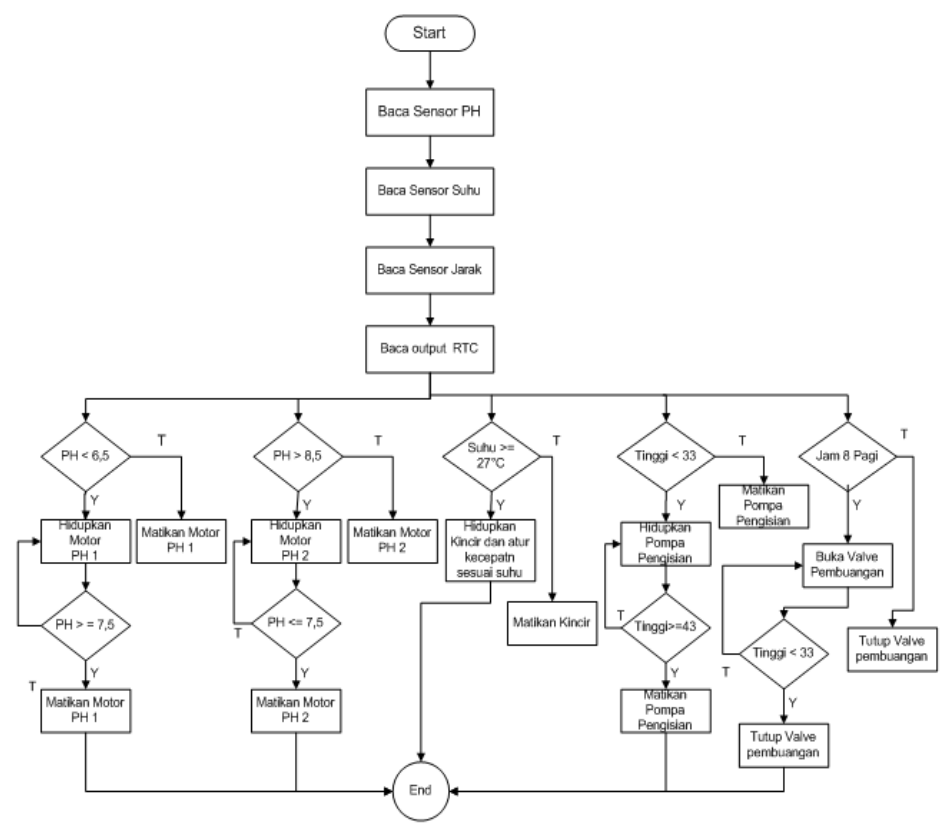

Gambar 2. Flowcard sistem yang ditanam ke dalam Arduino Uno

\section{Cara Kerja Sistem}

Setting port USB atau serial dengan band rete 9600 $8 \mathrm{n} 1$ ( kecepatan 9600 bit, 8 byte, $\mathrm{n}=$ nomor party, $1=$ stop bit/ tanda pemisah). Tes monitoring data serial dengan cara menghubungkan Arduino dengan setting port USB. Jika ada data dari mikrokontroler, maka langkah selanjutnya adalah membaca sensor $\mathrm{PH}$ yang terhubung ke port analog A0, kemudian sensor suhu yang terhubung ke port analog A1, kemudian sensor jarak ultrasonic yang terhubung ke port pin digital D5 dan input saklar pembuangan air ke port digital D11.

Motor PH 1 yang berfungsi untuk menginjeksikan larutan kapur terhubung pada port digital D7 akan aktif apabila nilai $\mathrm{PH}$ hasil pengukuran kurang dari 6,00 dan akan tetap aktif hingga nilai $\mathrm{PH}$ hasil pengukuran lebih atau sama dengan 7,5.

Motor PH 2 yang berfungsi untuk menginjeksikan larutan belerang terhubung pada port digital D8 akan aktif apabila nilai PH hasil pengukuran lebih 8,5, dan akan tetap aktif hingga nilai $\mathrm{PH}$ hasil pengukuran kurang atau sama dengan 7,5.

Valve yang berfungsi untuk melakukan pembuangan air pada bak yang terhubung pada port digital D2 akan aktif apabila saklar input port digital D11 ditekan, dan akan tetap aktif hingga ketinggian permukaan air kurang dari $35 \mathrm{~cm}$.

Pompa motor 3 yang berfungsi untuk melakukan pengisian air pada bak yang terhubung pada port digital D4 akan aktif apabila ketinggian permukaan air kurang dari 35 $\mathrm{cm}$, dan akan tetap aktif hingga ketinggian permukaan sudah mencapai $43 \mathrm{~cm}$.

Motor roda kincir yang digerakkan oleh $\mathrm{H}$ bridge 30A yang mendapatkan input PWM dari port digital PWM D9 akan berputar dengan kecepatan yang bergantung pada perubahan nilai temperatur dimana akan dicapai putaran maksimum pada suhu 37 derajat celcius.

\section{Pengujian Sistem}

Adapun tahap pengujian aplikasi meliputi :

1. Tahap diagnose awal Pada tahap ini akan dilakukan identifikasi masalah yang ada.

2. Tahap perancangan dan pembuatan Pada tahap ini dilakukan perancangan, menyediakan seluruh komponen yang dibutuhkan,selanjutnya merakit dan membuat alat, serta mengisi program program yang diperlukan. Komponen - komponen yang perlu di persiapkan diantaranya : PC atau Leptop, 1 modul arduino Uno, kabel USB, sensor $\mathrm{PH}$, sensor suhu, Sensor jarak ultrasonic.

Tahapan pembuatannya dimulai dengan menyiapkan Arduino Uno versi 0023 dan Borland Delphi 7 dan komponen comport library. Kemudian membuat program di arduino yang berfungsi untuk mambaca sensor analog dari sensor $\mathrm{Ph}$ dan suhu, dan digital dari sensor jarak ultrasonic. Setelah sensor tersebut terbaca, maka akan mengirimkan data ke komputer melalui port USB. Membuat program monitoring data sensor dari mikrokontroler ke PC dengan menggunakan bahasa pemrograman Borlan Delphi 7.

3. Tahap pengujian alat.

Pada tahap ini dilakukan pengujian dan pengetesan alat yaitu menguji secara langsung kerja alat, kemudian mengumpulkan data - datanya dan 
menyusunnya sebagai data hasil akhir penelitian. Pengujian dilakukan dengan menghubungkan PC dengan Arduino melalui kabel USB yang sudah terhubung dengan sensor-sensor yang digunakan. Kemudian melakukan verifikasi akurasi pembacaan data dari sensor tersebut.

4. Tahap evaluasi.

Pada tahap ini dilakukan evaluasi dan analisis secara keseluruhan hasil kerja alat dan kemudian mengambil kesimpulan dari cara kerja alat tersebut secara keseluruhan.

\section{Pengukuran dan Verifikasi}

Dari hasil pengukuran yang di peroleh dari pembacaan sensor pada tampilan monitoring dapat di lihat pada grafik berikut :

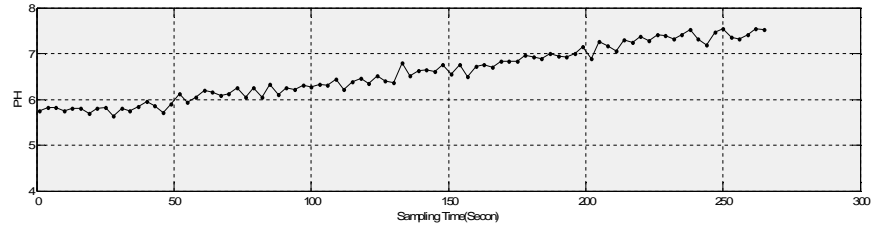

Gambar 3. Grafik pengujian saat nilai PH kurang dari 6,00

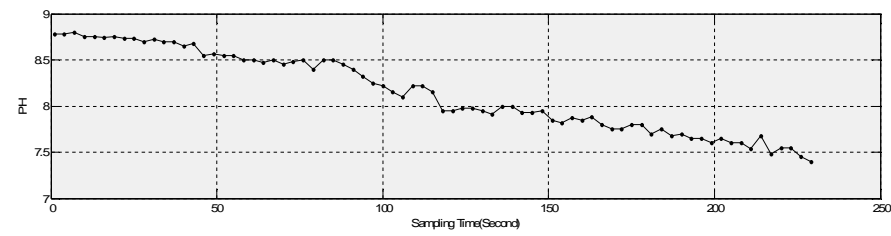

Gambar 4. Grafik pengujian saat nilai PH lebih dari 8,50

Dari data dan grafik pengujian saat PH kurang dari 6,00 yaitu 5,74 seperti terlihat pada waktu sampling pertama, maka akan dilakukan proses penginjeksian larutan kapur untuk menaikkan nilai $\mathrm{Ph}$ tersebut. Proses injeksi akan aktif hingga didapatkan nilai PH yang sama atau lebih besar dari 7,5 yaitu 7,54. Seperti yang terlihat pada data ke-84, dengan waktu sampling 330 detik.

Dari data dan grafik pengujian saat $\mathrm{PH}$ lebih dari 8,5 yaitu 8,78 seperti terlihat pada waktu sampling pertama, maka akan dilakukan proses penginjeksian larutan asam untuk menurunkan nilai $\mathrm{Ph}$ tersebut. Proses injeksi akan aktif hingga didapatkan nilai PH yang sama atau kurang dari 7,5 yaitu 7,48 . Seperti yang terlihat pada data ke-73 dengan waktu sampling 217 detik.

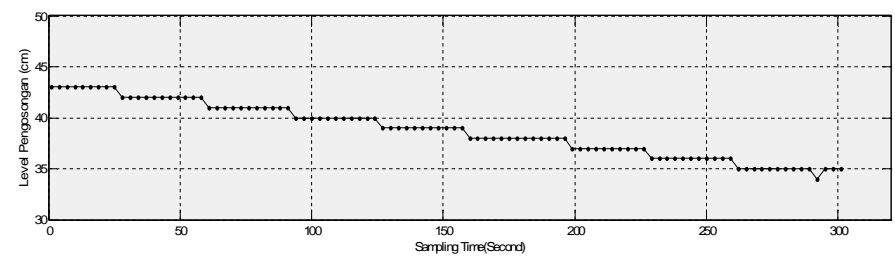

Gambar 5. Grafik pengujian saat dilakukan pembuangan air

Dari grafik di atas dapat dilihat saat dilakukan pembuangan air pada ketinggian $43 \mathrm{~cm}$, maka akan terjadi penurunan ketinggian permukaan air, dan proses ini akan terus aktif hingga permukaan air telah mencapai $34 \mathrm{~cm}$ seperti terlihat pada data yang ke-100. dengan waktu sampling 292 detik

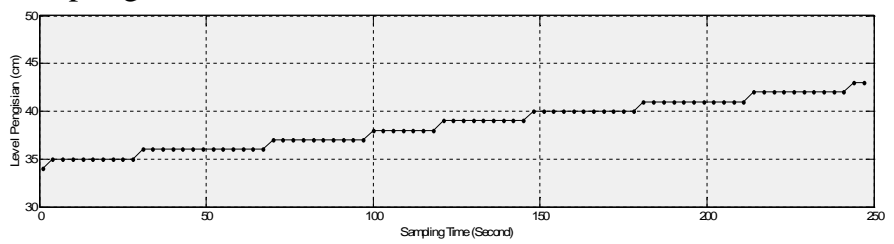

Gambar 6. Grafik pengujian saat dilakukan pengisian air

Dari grafik di atas dapat dilihat saat dilakukan pengisian air pada ketinggian $34 \mathrm{~cm}$, maka akan terjadi kenaikan ketinggian permukaan air, dan proses ini akan terus aktif hingga permukaan air telah mencapai $43 \mathrm{~cm}$ seperti terlihat pada data yang ke-82 dengan waktu sampling 247 detik
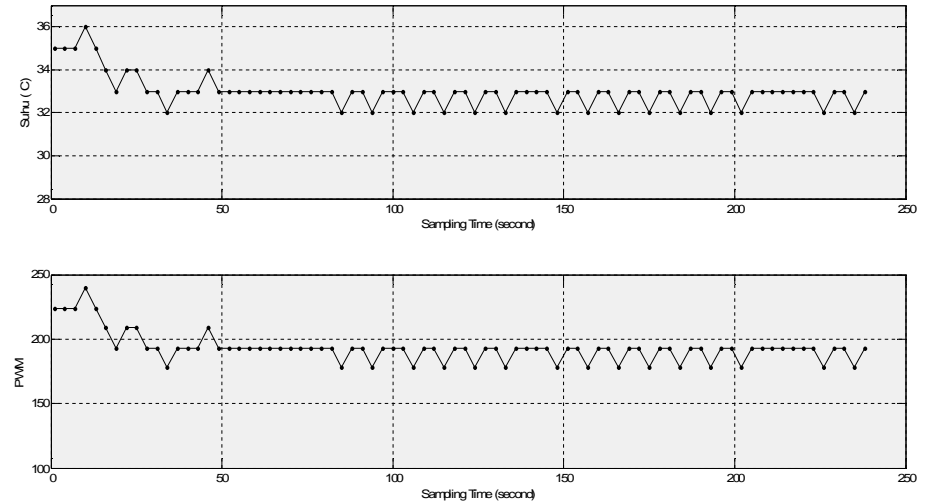

Gambar 4.12 Grafik pengujian perubahan suhu dan output PWM

Dari hasil pembacaan data dan grafik perubahan pembacaan sensor suhu sebagai referensi terhadap perubahan output PWM mikrokontroller, dimana pada saat temperature maksimium $36{ }^{\circ} \mathrm{C}$ output PWM 240 dengan tegangan output H-Bridge 11,38 volt. Pada temperature $35^{\circ} \mathrm{C}$ output PWM 224 dengan tegangan output H-Bridge 10,63 volt Pada temperature $34^{\circ} \mathrm{C}$ output PWM 209 dengan tegangan output H-Bridge 9,92 volt Pada temperature $33^{\circ} \mathrm{C}$ output PWM 193 dengan tegangan output H-Bridge 9,16 volt. Dan pada temperature minimum $32^{\circ} \mathrm{C}$ output $\mathrm{PWM} 178$ dengan tegangan output $\mathrm{H}$-Bridge 8,44 volt. 


\section{Penutup}

Kesimpulan yang dapat diambil pada penelitian ini adalah :

1. Dengan adanya sistem monitoring dan pengendalian dengan menggunakan arduino sebagai mikrokontroller, maka pengguna dalam hal ini petani tambak udang akan dimudahkan, karena sistem ini secara otomatis akan mengendalikan parameter-parameter yang sangat menentukan pada suatu tambak udang seperti PH suhu dan level air yang harus selalu dikontrol untuk diperoleh hasil panen yang lebih baik.

2. Sistem kontrol on-off dengan menggunakan dua buah pompa sebagai aktuator, ternyata dapat menjaga nilai PH pada range 6,00 sampai dengan 8,50. Dimana dari hasil pengujian pada saat nilai PH kurang dari batas minimum waktu yang dibutuhkan untuk mengembalikan ke nilai 7,50 sekitar 330 detik. Dan pada saat nilai PH lebih dari batas maksimum waktu yang dibutuhkan untuk mengembalikan ke nilai 7,50 sekitar 217 detik.

3. Nilai perubahan pembacaan sensor suhu sebagai referensi terhadap perubahan output PWM mikrokontroller, ternyata dapat mengatur kecepatan motor kincir dimana pada saat pengujian pada temperature maksimium $36{ }^{\circ} \mathrm{C}$ output PWM 240 dengan tegangan output $\mathrm{H}$-Bridge 11,38 volt. Pada temperature minimum $32^{\circ} \mathrm{C}$ output PWM 178 dengan tegangan output H-Bridge 8,44 volt.

4. Sistem kontrol on-off dengan menggunakan satu buah valve dan satu buah pompa sebagai aktuator, ternyata dapat menjaga level air pada ketinggian dengan range 34 $\mathrm{cm}$ sampai dengan $43 \mathrm{~cm}$. Dimana dari hasil pengujian pada saat dilakukan pembuangan air waktu yang dibutuhkan untuk mencapai batas minimum sekitar 292 detik. Dan pada saat dilakukan pengisian air waktu yang dibutuhkan untuk mencapai batas maksimum sekitar 247 detik.

Adapun saran yang dapat diambil pada penelitian ini adalah:

1. Untuk penyimpanan data hasil pembacaan dari sensor dapat di buatkan penyimpanan database sehingga dapat di buka hasil penyimpanan data yang terdahulu.

2. Dalam hal pengawasan dan monitoring lebih lanjut, dapat dipasangkan alat berupa wifi sehingga memudahkan untuk monitoring lewat jaringan

\section{Daftar Pustaka}

[1] Artanto Dian. 2012. Interaksi Arduino dan labVIEW.Elex Media Komputindo.

[2] Banzi Massimo. 2009. Getting Started With Arduino. Published by Make:Books, an imprint of Maker Media, a division of O'Reilly Media, Inc.

[3] Faludi Robert. 2011. Building Wireless Sensor Networks. Published by O'Reilly Media, Inc., 1005 Gravenstein Highway North, Sebastopol.

[4] Hac Anna. 2003. Warless Sensor Network Design. University of Hawaii at Manoa, Honolulu, USA.
[5] Iswanto. 2011. Belajar Mikrokontroler AT89S51 dengan Bahasa C. Penerbit Andi Yogyakarta.

[6] Joni I Made, Raharjo Budi. 2011. Pemrograman C dan Implementasinya. Penerbit Informatika Bandung.

[7] Kuswadi Son. 2007. Kendali Cerdas, Teori dan Aplikasi Praktisnya. Penerbit Andi Yogyakarta.

[8] McRoberts. M.R..2009. Arduino Starters Kit Manual.Published by Earthshine Design.

[9] Nurcahyo Sidik. 2012. Aplikadi dan Teknik Pemrograman AVr Atmel. Penerbit Andi Yogyakarta.

[10] Rachmad Antonius C. 2010. Algoritma dan Pemrograman dengan Bahasa C - Konsep, Teori, \& Implementasi.Penerbit Andi Yogyakarta.

[11] Syahrul. 2012. Mikrokontroler AVR ATmega8535.Penerbit Informatika Bandung.

[12] M. Ghufron H. Kordi K. 2010. Budi Daya Udang Laut. Penerbit Andi Yogyakarta.

[13] Dra. S. Rachmatun Suyanto, Ir. Enny Purbani Takarina. 2009. Panduan Budi Daya Udang Windu. Penerbit Swadaya Jakarta. 